\title{
SELEÇÃO DE PRIMERS ISSR PARA ANÁLISES DE DIVERSIDADE GENÉTICA EM Plathymenia reticulata Benth.
}

\author{
Lucimara Cruz de Souza ${ }^{1}$ \\ Adelson Lemes da Silva Júnior ${ }^{2}$ \\ Aléxia Gonçalves Pereira ${ }^{3}$ \\ Mariana Cruz de Souza ${ }^{4}$ \\ Kelmer Mozer Moro ${ }^{5}$ \\ Alessandra Abreu Rodrigues Vieira ${ }^{6}$ \\ Izabela Ferreira Ribeiro ${ }^{7}$ \\ Sustanis Horn Kunz ${ }^{8}$ \\ Fábio Demolinari de Miranda ${ }^{9}$
}

Resumo: O objetivo deste trabalho foi selecionar primers ISSR para serem utilizados em futuras análises de diversidade genética em populações naturais de $P$. reticulata. Amostras foliares de cinco indivíduos da espécie foram coletadas para extração e purificação de DNA. O DNA obtido das amostras foi submetido a ensaios de PCR utilizando 28 primers, seguida de eletroforese em gel de agarose para análise dos fragmentos amplificados. Foram selecionados 10 primers por possuírem número considerado de locos e boa definição dos fragmentos. Os primers selecionados geraram ao todo 121 fragmentos amplificados, sendo 54 polimórficos. Os marcadores moleculares ISSR utilizados nesse estudo permitiram revelar o polimorfismo em Vinhático, indicando que a utilização de 10 primers (44,62\% de polimorfismo) são suficientes para quantificar em estudos futuros a diversidade genética existente em indivíduos de $P$. reticulata.

Palavras-chave: Marcadores moleculares; Variabilidade genética; Vinhático.

\footnotetext{
${ }^{1}$ Mestranda em Genética e Melhoramento/ UFES, Brasil. E-mail: lucimaracruz15@hotmail.com.

2 Mestre em Genética e Melhoramento/ UFES, Brasil. E-mail: adelsonlemes@yahoo.com.br.

${ }^{3}$ Bióloga/ UFES, Brasil. E-mail: alexiagp@gmail.com.

${ }^{4}$ Agronomia/UFES, Brasil. E-mail: scruz.mariana@gmail.com.

${ }^{5}$ Ciências Biológicas/UFES, Brasil. E-mail: kelmer.moro@gmail.com.

${ }^{6}$ Doutoranda em Genética e Melhoramento/ UFES, Brasil. E-mail: abreuepires@gmail.com.

${ }^{7}$ Mestranda em Biodiversidade Tropical/UFES, Brasil. E-mail: izabelafribeiro@gmail.com.

8 Prof. Doutora em Ciências Florestais/UFES, Brasil. E-mail: sustanis@gmail.com.

${ }^{9}$ Prof. Doutor em Genética e Melhoramento/UFES, Brasil. E-mail: fademolinari@yahoo.com.br.
} 